ҚАЗАҚСТАН РЕСПУБЛИКАСЫ

ҰЛТТЫҚ ҒЫЛЫМ АКАДЕМИЯСЫНЫН

АБАЙ АТЫНДАҒЫ ҚАЗАҚ ҰЛТТЫҚ

ПЕДАГОГИКАЛЫҚ УНИВЕРСИТЕТІНІҢ

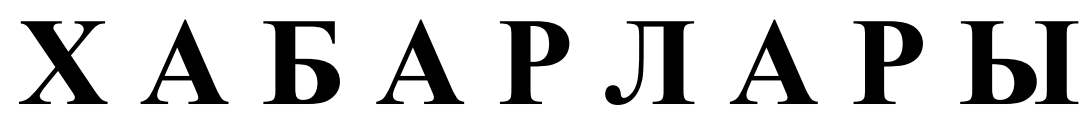

\section{ИЗВЕСТИЯ}

НАЦИОНАЛЬНОЙ АКАДЕМИИ НАУК РЕСПУБЛИКИ КАЗАХСТАН

КАЗАХСКИЙ НАЦИОНАЛЬНЫЙ

ПЕДАГОГИЧЕСКИЙ УНИВЕРСИТЕТ ИМ. АБАЯ

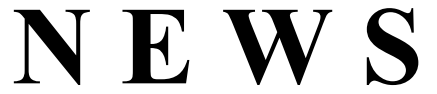

OF THE NATIONAL ACADEMY OF SCIENCES OF THE REPUBLIC OF KAZAKHSTAN

ABAY KAZAKH NATIONAL PEDAGOGICAL UNIVERSITY

ҚОҒАМДЫҚ ЖӘНЕ ГУМАНИТАРЛЫҚ ҒЫЛЫМДАР СЕРИЯСЫ

СЕРИЯ ОБЩЕСТВЕННЫХ И ГУМАНИТАРНЫХ НАУК

SERIES OF SOCIAL AND HUMAN SCIENCES

\author{
6 (322) \\ ҚАРАША - ЖЕЛТОҚСАН 2018 ж. \\ НОЯБРЬ - ДЕКАБРЬ 2018 Г. \\ NOVEMBER - DECEMBER 2018 \\ ИЗДАЕТСЯ С ЯНВАРЯ 1962 ГОДА \\ PUBLISHED SINCE JANUARY 1962 \\ ЖЫЛЫНА 6 РЕТ ШЫҒАДЫ \\ ВЫХОДИТ 6 РАЗ В ГОД \\ PUBLISHED 6 TIMES A YEAR
}

1962 ЖЫЛДЫҢ ҚАНТАР АЙЫНАН ШЫҒА БАСТАҒАН 
Ба с ре дактор

ҚР ҰҒА кұрметті мүшесі

Балықбаев Т.O.

Р е д а ц и я а лқ а сы:

экон. ғ. докторы, проф., ҚР ҰҒА академигі Баймұратов У.Б.; тарих ғ. докторы, проф., ҚР ҰҒА академигі Байпақов К.М.; филос. ғ.докторы, проф., ҚР ҰҒА академигі Есім Г.Е.; фил. ғ. докторы,, проф., ҚР ҰҒА академигі Қирабаев С.С.; эк. ғ. докторы, проф., ҚР ҰҒА академигі Кошанов А.К.; эк.ғ. докторы, проф., ҚР ҰҒА академигі Нәрібаев К.Н. (бас редактордың орынбасары); филос. ғ.докторы, проф., ҚР ҰҒА академигі Нысанбаев А.Н.; заң ғ. докторы, проф., ҚР ҰҒА академигі Сәбікенов С.Н.; заң ғ. докторы, проф., ҚР ҰҒА академигі Сүлейменов М.К.; эк. ғ. докторы, проф., ҚР ҰҒА академигі Сатыбалдин С.С.; тарих ғ. докторы, проф., ҚР ҰҒА академик Әбжанов Х.М.; тарих ғ. докторы, проф., ҚР ҰҒА корр. мүшесі Әбусеитова М.Х.; тарих ғ. докторы, проф., ҚР ҰҒА академик Байтанаев Б.А.; филол. ғ. докторы, проф., ҚР ҰҒА корр. мүшесі Жақып Б.А.; фил. ғ. докторы, проф., академик НАН РК Қалижанов У.К.; филол. ғ. докторы, проф., ҚР ҰҒА академик Қамзабекұлы Д.; тарих ғ. докторы, проф., ҚР ҰҒА академик Қожамжарова Д.П.; тарих ғ. докторы, проф., ҚР ҰҒА академик Койгелдиев М.К.; фил. ғ. докторы, проф., ҚР ҰҒА корр. мүшесі Кұрманбайұлы Ш.; тарих ғ. докторы, проф., ҚР ҰҒА корр. мүшесі Таймағанбетов Ж.К.; социол. ғ. докторы, проф., ҚР ҰҒА корр. мүшесі Шәукенова 3.К.; фил. ғ. докторы, проф., КР ҰҒА корр. мүшесі Дербісәлі А.; саяси. ғ. докторы, проф., Бижанов А.К., тарих ғ. докторы, проф., Кабульдинов 3.Е.; фил. ғ. докторы, проф., ҚР ҰҒА корр мүшесі Қажыбек Е.3.

\section{Р едакция ке н е с i:}

Молдова Республикасының ҰҒА академигі Белостечник Г. (Молдова); Әзірбайжан ҰҒА академигі Велиханлы Н. (Азербайджан); Тәжікстан ҰҒА академигі Назаров Т.Н. (Тәжікстан); Молдова Республикасының ҰҒА академигі Рошка А. (Молдова); Молдова Республикасының ҰҒА академигі Руснак Г. (Молдова); Әзірбайжан ҰҒА корр. мүшесі Мурадов Ш. (Әзірбайжан); Әзірбайжан ҰҒА корр. мүшесі Сафарова 3. (Әзірбайжан); э. ғ. д., проф. Василенко В.Н. (Украина); заң ғ. докт., проф. Устименко В.А. (Украина)

«Қазақстан Республикасы Ұлттық ғылым академиясының Хабарлары. Қоғамдық және гуманитарлық ғылымдар сериясы». ISSN 2224-5294

Меншіктенуші: «Қазақстан Республикасының Ұлттық ғылым академиясы» РҚБ (Алматы қ.)

Қазақстан республикасының Мәдениет пен ақпарат министрлігінің Ақпарат және мұрағат комитетінде 30.04.2010 ж. берілген № 10894-Ж мерзімдік басылым тіркеуіне қойылу туралы куәлік

Мерзімділігі: жылына 6 рет.

Тиражы: 500 дана.

Редакцияның мекенжайы: 050010, Алматы қ., Шевченко көш., 28, 219 бөл., 220, тел.: 272-13-19, 272-13-18, http://nauka-nanrk.kz. social-human.kz

(C) Қазақстан Республикасының Ұлттық ғылым академиясы, 2018

Типографияның мекенжайы: «Аруна» ЖК, Алматы қ., Муратбаева көш., 75. 
Главный редактор

Почетный член НАН РК

T.O. Балыкбаев

Р е дак ци онн а я коллег и я:

докт. экон. Н., проф., академик НАН РК У.Б. Баймуратов; докт. ист. н., проф., академик НАН РК К.М. Байпаков; докт. филос. Н., проф., академик НАН РК Г.Е. Есим; докт. фил. Н., проф., академик НАН РК С.С. Кирабаев; докт. экон. Н., проф., академик НАН РК А.К. Кошанов; докт. экон. Н., проф., академик НАН РК К.Н. Нарибаев (заместитель главного редактора); докт. филос. н., проф., академик НАН РК А.Н. Нысанбаев; докт. юр. Н., проф., академик НАН РК С.Н. Сабикенов; докт. юр. н., проф., академик НАН РК М.К. Сулейменов; докт. экон. Н., проф., академик НАН РК С.С. Сатубалдин; докт. ист. н., проф., академик НАН РК Х.М. Абжанов; докт. ист. н., проф., чл.-корр. НАН РК М.Х. Абусеитова; докт. ист. н., проф., академик НАН РК Б.А. Байтанаев; докт. фил. н., проф., чл.-корр. НАН РК Б.А. Жакып; докт. фиолол. н., проф., академик НАН РК У.К. Калижанов; докт. фил. н., проф., академик НАН РК Д. Камзабекулы; докт. ист. н., проф., академик НАН РК Д.П. Кожамжарова; докт. ист. н., проф., академик НАН РК М.К. Койгельдиев; докт. филол. н., проф., чл.-корр. НАН РК Ш. Курманбайулы; докт. ист. н., проф., чл.корр. НАН РК Ж.К. Таймаганбетов; докт. социол. н., проф., чл.-корр. НАН РК З.К. Шаукенова; д. филол. н., проф., чл.-корр. НАН РК А. Дербисали; доктор политических наук, проф., Бижанов А.К.; доктор ист. наук, проф., Кабульдинов 3.Е.; доктор филол. н., проф., член-корр. НАН РК Қажыбек Е.3.

Р е дак ци онны й с ов ет

академик НАН Республики Молдова Г. Белостечник (Молдова); академик НАН Азербайджанской Республики Н. Велиханлы (Азербайджан); академик НАН Республики Таджикистан Т.Н. Назаров (Таджикистан); академик НАН Республики Молдова А. Рошка (Молдова); академик НАН Республики Молдова Г. Руснак (Молдова); чл.-корр. НАН Азербайджанской Республики Ш. Мурадов (Азербайджан), член-корр. НАН Азербайджанской Республики 3.Сафарова (Азербайджан); д. э. н., проф. В.Н. Василенко (Украина); д.ю.н., проф. В.А. Устименко (Украина)

Известия Национальной академии наук Республики Казахстан. Серия общественных и гуманитарных наук. ISSN 2224-5294

Собственник: РОО «Национальная академия наук Республики Казахстан» (г. Алматы)

Свидетельство о постановке на учет периодического печатного издания в Комитете информации и архивов

Министерства культуры и информации Республики Казахстан № 10894-Ж, выданное 30.04.2010 г.

Периодичность 6 раз в год

Тираж: 500 экземпляров

Адрес редакции: 050010, г. Алматы, ул. Шевченко, 28, ком. 219, 220, тел. 272-13-19, 272-13-18, www:nauka-nanrk.kz / social-human.kz

(C) Национальная академия наук Республики Казахстан, 2018 г.

Адрес типографии: ИП «Аруна», г. Алматы, ул. Муратбаева, 75

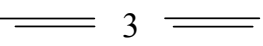


Chief Editor

\section{Honorary member of NAS RK \\ Balykbayev T.O}

Editorial board:

Doctor of economics, prof, academician of NAS RK Baimuratov U.B.; doctor of history, prof, academician of NAS RK Baipakov K.M.; doctor of philosophy, prof, academician of NAS RK Esim G.E.; doctor of philology, prof, academician of NAS RK Kirabayev S.S.; doctor of economics, prof, academician of NAS RK Koshanov A.K.; doctor of economics, prof, academician of NAS RK Naribayev K.N. (deputy editor-in-chief); doctor of philosophy, prof, academician of NAS RK Nyssanbayev A.N.; doctor of law, prof, academician of NAS RK Sabikenov S.N.; doctor of law, prof, academician of NAS RK Suleymenov M.K.; doctor of economy, prof, academician of NAS RK Satybaldin S.S.; doctor of history, prof, academician of NAS RK Abzhanov H.M; doctor of history, prof, corresponding member of NAS RK Abuseitova M.H.; doctor of history, prof, academician of NAS RK Baitanaev B.A.; doctor of philology, prof, corresponding member of NAS RK Zhakyp B.A.; doctor of philology, prof, academician of NAS RK Kalizhanov U.K.; doctor of philology, prof, academician of NAS RK Hamzabekuly D.; doctor of history, prof, academician of NAS RK Kozhamzharova D.P.; doctor of history, prof, academician of NAS RK Koigeldiev M.K.; doctor of philology, prof, corresponding member of NAS RK Kurmanbaiuly Sh.; doctor of history, prof, academician of NAS RK Taimaganbetov J.K.; doctor of sociology, prof, corresponding member of NAS RK Shaukenova Z.K.; doctor of philology, prof, corresponding member of NAS RK Derbisali A.; doctor of political science, prof Bizhanov A.K; doctor of History, prof Kabuldinov Z.E.; doctor of philology, prof, corresponding member of NAS RK Kazhybek E.Z.

\section{Editorial staff:}

Academician NAS Republic of Moldova Belostechnik.G (Moldova); Academician NAS Republic of Azerbaijan Velikhanli N. (Azerbaijan); Academician NAS Republic of Tajikistan Nazarov T.N. (Tajikistan); Academician NAS Republic of Moldova Roshka A. (Moldova) Academician NAS Republic of Moldova Rusnak G. (Moldova); Corresponding member of the NAS Republic of Azerbaijan Muradov Sh. (Azerbaijan); Corresponding member of the NAS Republic of Azerbaijan Safarova Z. (Azerbaijan); Associate professor of Economics Vasilenko V.N. (Ukraine), Associate professor of Law Ustimenko V.A. (Ukraine)

News of the National Academy of Sciences of the Republic of Kazakhstan. Series of Social and Humanities. ISSN 2224-5294

Owner: RPA "National Academy of Sciences of the Republic of Kazakhstan" (Almaty)

The certificate of registration of a periodic printed publication in the Committee of information and archives of the Ministry of culture and information of the Republic of Kazakhstan N 10894-Ж, issued 30.04.2010

Periodicity: 6 times a year

Circulation: 500 copies

Editorial address: 28, Shevchenko str., of. 219, 220, Almaty, 050010, tel. 272-13-19, 272-13-18, www:nauka-nanrk.kz / social-human.kz

(C) National Academy of Sciences of the Republic of Kazakhstan, 2018

Address of printing house: ST "Aruna", 75, Muratbayev str, Almaty 
N E W S

OF THE NATIONAL ACADEMY OF SCIENCES OF THE REPUBLIC OF KAZAKHSTAN

SERIES OF SOCIAL AND HUMAN SCIENCES

ISSN 2224-5294

Volume 6, Number 322 (2018), $214-219$

https://doi.org/10.32014/2018.2224-5294.56

МРНТИ 06.81.12

UDC 330.131 .7

\author{
Ye. N. Nesipbekov ${ }^{1}$, G.N.Appakova ${ }^{2}$ \\ ${ }^{1}$ Almaty Technological University, Almaty, Republic of Kazakhstan; \\ ${ }^{2}$ Narxoz University, Almaty, Republic of Kazakhstan, \\ e-mail: nesipbekov@mail.ru ganek310@mail.ru
}

\title{
THEORETICAL ASPECTS OF THE ENTERPRISE INVESTMENT PORTFOLIO SET-UP
}

\begin{abstract}
Present article is aimed to reveal the main theoretical aspects and practical methods for the enterprise portfolio set-up. General scientific principles constitute the methodological basis of the study; principle of the consciousness and activity unity; subjectivity principle; consistency principle; principle of development, as well as the main provisions of the investment portfolio set-up.

Three fundamental theories of the investment portfolio set-up are described in the study, including their significance and negative aspects, the method of investment portfolio set-up is analyzed as well as phased description. The article is focused on the ratio of such indicators as investment risks and investment returns, investment returns and investment liquidity. It is noted that the balance of these indicators makes fundamental principle for the investment portfolio set-up. At the end of the article, the authors concluded that existing paradigm of the stability investment portfolio analysis via the risk probabilities determination is not efficient enough and shall be supplemented with stability analysis even at low risks.

The main findings of the study may be used as methodological basis for the further deepening research on this matter.
\end{abstract}

Keywords: investment portfolio, investment strategy, models of the investment portfolios set-up, investment projects.

\section{Introduction}

Currently, significant changes are noted in the approaches to determine the risks and riskiness of various enterprises. The growing uncertainty of the external environment is noted in respect of enterprise, that complicates to predict possible negative events. In this condition, set-up of the investment portfolio for the enterprise becomes an opportunity to minimize the losses from the negative probabilities meanwhile keeping the ability to allocate capital in the promising projects that would enable the company's long-term plans implementation.

There are several reasons why the company seeks to optimize the process of investment portfolio setup to the maximum:

First, the portfolio with synergistic properties improves the enterprise investment attractiveness for the third party investors. That brings the enterprise value increase. Second, investment portfolio becomes the tool to identify the hidden value of assets owned by the company. Third, investment portfolios are highly optional - that is, in fact, the effective tool for the management of uncertainties and risks associated, among other, to the external environment of enterprise.

In addition, the use of portfolio investment enables the company to enter the new markets, upload idle production facilities and redirect cash flows to the more productive direction.

\section{Results and discussion}

The enterprise investment portfolio set-up is one of the main stages in the company's long-term investment strategy formation. Meanwhile it is necessary to keep in mind a set of factors in this process: interests of shareholders, mutual influence and co-dependency of projects within the single portfolio, emergence of synergies, portfolio balance as a whole. 
The enterprise investment portfolio is a combination of various investment projects. The investment project is the action plan related to capital investments, their investment and the subsequent generation of profits. Each investment project has its own aim and that shall help to achieve the goal of the investment portfolio the project belongs to. At the same time, projects may be linked both by the common process chain and potential synergistic effects [1].

Significant amount of theoretical works is devoted to the problems of the enterprise investment portfolio set-up. G. Markowitz was one of the first researchers engaged in the investment and expected returns, who developed the Markowitz theory of the investment portfolio set-up. This theory provides the enterprise motivation to form the least risky portfolio, and obtain the additional profit for additional risk. The model assumes the investor to be guided with two factors only while making decisions.

1) average and expected returns from the portfolio;

2) risk measured by standard deviation or variance [2].

The Markowitz model is one of the most significant one in the modern financial theory, but it has a number of drawbacks. First, the methods used for pricing the profitability and risks may bring significant inaccuracies or a range of probabilities, that embarrasses the decision making, and second, the model considers only risky assets.

Another common theory is the "capital asset pricing model". A number of scientists including W. Sharp, G. Alexander, J. Bailey further developing the Markowitz theory segregated the risks in the investment portfolio into market (systematic) and own (non-systematic). An important contribution of the theory is that the portfolio diversification reduces its overall risk. This is due to decrease in the portfolio's own risk, since fluctuations cycles of the risks and profitability in each project portfolio do not coincide. At the same time, the investor shall not take into account all the portfolio related risks now (according to Markowitz), but only his own risk, since he is not able to affect the market. However, this model also has a drawback - set-up of portfolio using the risk-free assets it poorly analyzed.

R. Ross additionally studied this matter. He proposed another theory called the arbitration pricing model (APM). Within this model, the concept of arbitration was introduced - a situation when enterprise may invest without risk and earn more than under risk-free rate. The main assumption of this model is that investors take the opportunity to make a profit on the price difference without taking any risk [3].

While portfolio set-up, any company pursues the main goal - to increase the business value keeping the investments reliability and profitability [4]. At the same time, operating activity shall not be affected by the investment activity of the enterprise - it is a matter of the funds liquidity. The main goal of the portfolio set-up includes the following subgoals:

1. Ensuring the capital growth rate via inclusion of real and financial investment, the value of which may increase in the investment portfolio.

2. High liquidity of the part of portfolio assets for quick reinvestment in case of market situation changes and other difficulties inside the company.

3. Ensuring the growth rate of investment income including the investments with high interest and dividends payable in the portfolio.

4. Ensuring the low level of investment risks via the portfolio leveling including the various unrelated projects.

These sub-goals of the company's investment portfolio set-up are closely intertwined.

In general, the following principles of the portfolio set-up can be distinguished:

- portfolio compliance with the funds available for investment;

- implementation of the investment strategy;

- optimal ratio of profitability and liquidity;

- optimal ratio of profitability and risk;

- ongoing monitoring of the investment portfolio;

- portfolio manageability.

Compliance with the risk and return ratio is an important principle of the investment portfolio set-up. The risks of investment project are subject to unsuccessful marketing strategy and other internal factors, as 
well as changes to legislation, restrictions related to the industry activities implementation and economic situation in the country. Therefore, each company shall periodically develop countermeasures to risk events and develop different event scenarios.

The matter of the optimal ratio of investment return and liquidity has always been relevant for the enterprises. Thus, in addition to high-risk projects, high-yield investments include real estate, equipment, etc., the market price of which may increase. However, investment in the fixed assets may reduce the enterprise liquidity - its ability to pay off operating expenses quickly.

For example, the increase in the securities rate of return entails the increase in investment risk. And real investments are quite high-yielding, but at the same time low-liquid. Therefore, while setting up the investment portfolio, enterprises shall monitor their balance of indicators (Fig. 1).

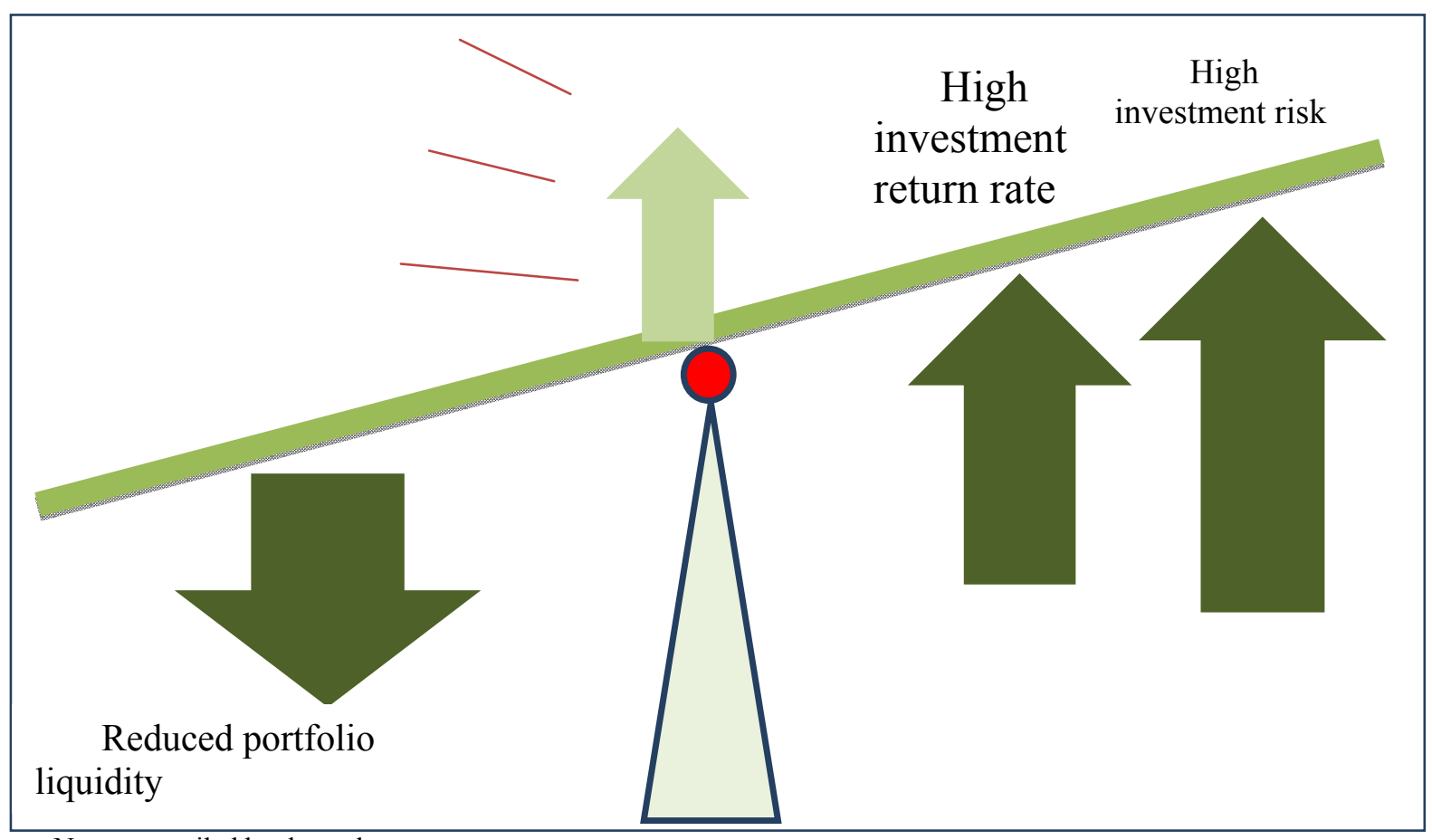

Note - compiled by the authors

Figure 1 - Status of the investment portfolio indicators

As for the practical methods of the enterprise investment portfolio set-up, there is an algorithm of the enterprise investment portfolio set-up, consisting of seven stages [5]:

1) Selection of the projects for investment portfolio - so-called formation of the bank of projects. At this stage, the most promising options are searched in terms of implementation. Business plan is made for each project as well as the main technological, environmental, social and economic parameters of the projects are calculated and checked for their compliance with the minimum requirements of the enterprise. Significant economic parameters are return on investments ROIC, return index (PI), Internal Rate of Return (IRR), Payback Period (PP), Discounted Payback Period (DPP) that is, relative indicators that determine the project efficiency, for which the enterprise, as a rule, sets threshold values. Next, the most suitable projects for the enterprise are selected from the bank (both from the economic point of view and image).

2) Assessment of the project implementation interaction separately and enterprise strategy; ranking projects depending on the impact to the strategic goals implementation. Finally, the projects are listed from the larger to the smaller one depending on their investment attractiveness.

3) Calculation of the project rating based on the second stage analysis. Depending on the project requirements, rating calculation complexity, necessary information, and time required for analysis may vary. The most common and universal estimation methods are given by the scientists M. Ehrhart and Y. 
Brigham [6]. At this stage of the investment portfolio set-up, it is necessary to analyze not only the economic aspects of the investment project implementation, but image, social, environmental aspects as well. In addition, it is necessary to check the project adequacy to the rest entire project.

Herewith the formula for the rating calculation:

(1). $R=\sqrt{\sum_{i=1}^{n} p_{i}(1-\omega)^{2}}$

where $\mathrm{R}$ - rating of the project investment attractiveness; $\omega$ - normalized i-value:

(2). $\omega=1-\frac{x}{x_{n}},-$ for standardized ratio,

(3). $\omega=1-\frac{x_{n}}{x}$, - for indicators representing the opposite effect.

$\mathrm{x}_{\mathrm{n}}$ - target value;

$\omega$ - rated indicator value

$\mathrm{p}_{\mathrm{i}}$ - $\mathrm{i}$-score weight

The final rating of the investment attractiveness indicates the degree of the key indicators approximation to the target (ideal) value. The closer the rating to 1, the more attractive the project for investment.

4) Additional stage of selection, when preliminary plans of the investment portfolio set-up are considered subject to the projects selected upon the rating. It is necessary to correlate selected projects with existing ones in order to exclude duplicates, and those that do not meet the enterprise requirements in terms of its development stage adequacy at that point of time.

5) Feasibility verification of the projects from the point of resource intensity. The capital budget amount is the most frequent limitation of the project resource intensity. If there are several projects, then other criteria are added to the verification, i.e. the most resource-intensive project is not necessarily the most important, and vice versa - the least resource-intensive project is the least important.

6) At this stage, the interests of the shareholders or equity stakes of the company are assessed. It is necessary to keep in mind the holders' interests consistency factor, since even if there are high indicators of formal criteria at the early stages, the project inconsistent to the holders' interests is most likely ineffective.

The main categories of stakeholders are described in the article of Anikina I.D. [5]:

a) capable to impact directly to the decision of the investment project selection: shareholders, creditors, and other investors. The acceptance or rejection of the project depends on them.

б) capable to impact only indirectly: employees of the enterprise, members of their families, municipal and republican authorities, business partners of the enterprise. The effectiveness of the project implementation and its investment attractiveness depend on them.

The interests of such huge number of heterogeneous groups associated with the project may differ significantly, therefore, the nature of their decision regarding the project implementation may be different.

7) Assessment of the investment portfolio as a whole, as one single project, when investment projects make its integral parts. At this stage, the time factor is of the utmost importance - the timeliness of the portfolio goals achievement, optimization of the capital investments via timely redirection of free funds to the necessary projects, time matching the end of one project to the start of another one. Based on necessity to assess the portfolio, the entire calculation is made in two stages - first, the value of enterprise is calculated without the entire portfolio, and then including the portfolio, also entirely including the synergistic effects that arise, changes in risks and favorable probabilities. All this enables us to assess the portfolio as a whole, but not as the sum of incoming investment projects. Whereas the synergistic effects may occur in six different directions, such as innovations (gaining know-how from the excessive funding), operational (changing operating leverage due to changes in cost structure), marketing (entering new markets, increasing the share of the existing markets), financial (increase in financial flexibility and stability of the portfolio), competence (improvement of the management quality, optimization of the organizational chart) and speculative (investment in the projects with high potential cost growth) [7].

The above stages enable us to analyze all key aspects of the investment portfolio set up consistently, from the smallest to the largest, taking into account the most significant groups of factors in the enterprise 
long-term strategy implementation. In addition, they provide a methodological basis for the analysis of similar investment projects making minor adjustments, that means they are not highly specialized and can be used by the enterprise in a number of similar tasks.

\title{
Conclusion
}

Modern theoretical models of the investment portfolios set-up devote most attention to the risk prediction, its probabilities, while even an unlikely risk under sufficiently enough consequences, if it occurs may destroy any long-term plan and bring the company to the losses or collapse. Consequently, while the investment portfolio set-up, more attention shall be devoted not to the probability of the event occurrence (keeping this aspect in mind), but to the consequences of this event and possibilities to decrease possible impact. This gives us qualitatively different approach for the investment portfolio set-up - not forecasting the probability of risks, but forecasting the enterprise sustainability with the worst possible outcome.

\section{REFERENCES}

[1] Gibson R. (2008) Formirovanie investicionnogo portfelja: upravlenie finansovymi riskami: per. s angl. - M. : Al'pina Biznes Buks, 20 p.

[2] Popkova K. A., Pokataeva E. P., Jakovleva E.A. Formirovanie investicionnogo portfelja predprijatija v mezhdunarodnoj srede. Lesotehnicheskij zhurnal. 2013. №2 (10). P.193-197

[3] Jakovleva E., Chernyshev A. Regional'nye modeli razvitija kooperacii i integracii v reformiruemom APK. APK: Jekonomika, upravlenie. 2005. №5. P.39-46

[4] Benko, K. (2007) Upravlenie portfeljami proektov: sootvetstvie proektov strategicheskim celjam kompanii: per. s angl.. M.: OOO «I.D. Vil'jams», 240 p.

[5] Anikina I. D. Formirovanie investicionnogo portfelja predprijatija: metodicheskie aspekty. Vestnik VolGU. Serija 3: Jekonomika. Jekologija. 2011. №1. P.145-153

[6] Brighem Ju.(2007) Finansovyj menedzhment. Ju. Brighem, M. Jerhart; per. s angl. pod red. k.je.n. E.A. Dorofeeva. 10-e izd. SPb.: Piter, 960 p.

[7] A.A. Nurpeisova , I.Yu. Rey, D.T. Bizhanov, D.A.Tleuzhanova. Main elements of managing the process of creating innovation production // News of the National Academy of Sciences of the Republic of Kazakhstan series of social and human sciences. 2018. Volume 5, Number 321. P. 53 - 56. https://doi.org/10.32014/2018. 2224-5294.9

\author{
Е. Н. Несіпбеков ${ }^{1}$, Г.Н. Аппакова ${ }^{2}$ \\ ${ }^{1}$ Алматы технологиялық университеті, Алматы, Қазақстан; \\ ${ }^{2}$ Нархоз Университеті, Алматы, Қазақстан \\ КӘСІПОРЫННЫҢ ИНВЕСТИЦИЯЛЫҚ ПОРТФЕЛІН \\ ҚАЛЫПТАСТЫРУДЫҢ ТЕОРИЯЛЫҚ АСПЕКТІЛЕРІ
}

\begin{abstract}
Аннотация. Мақаланың мақсаты - кәсіпорынның инвестициялық қоржынын қалыптастырудың негізгі теориялық аспектілерін және тәжірибелік әдістерін қарастыру. Зерттеудің әдістемелік негізін танымның жалпы ғылыми қағидалары; сана мен қызметтің бірегейлігі қағидасы; субъективтілік, жүйелік, даму қағидалары, сонымен қатар инвестициялық портфельді қалыптастырудың негізгі жайттары құрады.

Зерттеуде инвестициялық саясатты қалыптастырудың негізін қалаған үш теорияға сипаттама берілген, олардың маңыздылығы мен кемшіліктері көрсетілген. Мақалада инвестициялық тәуекелдер және инвестициялардың табыстылығы, инвестициялардың табыстылығы мен тез арада өтелуі сияқты көрсеткіштердің өзара байланыстылығына аса көңіл бөлінген. Мақаланың соңында авторлар келген ұйғарымға сәйкес, қолданыстағы тәуекелдер ықтималдығын анықтау арқылы инвестициялық қоржынынның тұрақтылығын талдау парадигмасының тиімділігі мардымсыз, сондықтан тәуекелдер деңгейі төмен болған жағдайда да тұрақтылықты талдаумен толықтырылуы тиіс.

Зерттеудің негізгі түйіндемелері осы мәселені әрі қарай зерттеу үшін әдістемелік негіз ретінде қолданылуы мүмкін.

Түйін сөздер: инвестициялық қоржын, инвестициялық стратегия, инвестициялық қоржынды қалыптастыру үлгілері, инвестициялық жобалар.
\end{abstract}




\section{Е.Н. Несипбеков ${ }^{1}$, Г.Н. Аппакова ${ }^{2}$}

${ }^{1}$ Алматинский технологический университет, Алматы, Республика Казахстан;

${ }^{2}$ Университет Нархоз, Алматы, Республика Казахстан,

\section{ТЕОРЕТИЧЕСКИЕ АСПЕКТЫ ФОРМИРОВАНИЯ ИНВЕСТИЦИОННОГО ПОРТФЕЛЯ ПРЕДПРИЯТИЯ}

Аннотация. Цель статьи - раскрытие основных теоретических аспектов и практических методов формирования инвестиционного портфеля предприятия. Методологическую основу исследования составили общенаучные принципы познания; принцип единства сознания и деятельности; принцип субъектности; принцип системности; принцип развития, а также основные положения формирования инвестиционного портфеля.

В исследовании дано описание трём основополагающим теориям формирования инвестиционного портфеля, показаны их значимость и отрицательные стороны, проанализирован метод формирования инвестиционного портфеля с поэтапным описанием. В статье особое внимание уделено взаимосвязи таких показателей, как инвестиционные риски и доходность инвестиций, доходность инвестиций и ликвидность вложений. Отмечено, что соблюдение баланса между этими показателями является основополагающим принципом формирования инвестиционного портфеля. В конце статьи авторы приходят к выводу, что существующая парадигма анализа устойчивости инвестиционного портфеля через определение вероятностей рисков недостаточна эффективна и должна быть дополнена анализом устойчивости даже при низких рисках.

Основные выводы исследования могут быть использованы в качестве методической основы для дальнейшего углубления исследований по данной проблеме.

Ключевые слова: инвестиционный портфель, инвестиционная стратегия, модели формирования инвестиционных портфелей, инвестиционные проекты.

Information about authors:

Nesipbekov E.N. - Almaty Technological University, associate professor, nesipbekov@ mail;

Appakova G.N. - University Narhoz, professor, ruganek310@mail.ru 


\section{МАЗМҰНЫ}

Беспаева Р.С., Бугубаева Р.О., Мануэль Ф. Грела2. Көрсеткіштердің теңдестірілген жүйесі негізінде Щучинск-Бурабай курорттық аймағын дамытудың кешенді стратегиясын қалыптастыру ................................................................................ 5

Аюпова 3.К., Құсайынов Д.Ө.Азаматтық процесстерді жетілдірудегі интеграцияның кейбір қырлары...................... 13

Құсайынова А. А., Вальдемар Козловски, Геращенко И. П.Қазақстан республикасындағы міндетті әлеуметтік сақтандырудың қаржылық-құқықтық тетіктерінің ерекшеліктері.

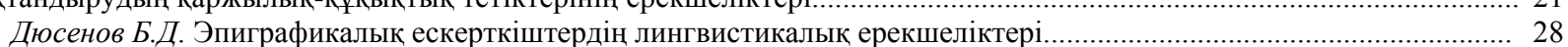

Джумадилова Ш.Г., Атабай Б.Ж. Қазақстандағы халықтың жинақтарының динамикасы......................................... 33

Карабалина А.А., Альситова А. Б., Кереймаганбетова Ж.Н., Абишева Н. М. Құндылық - рухани-адамгершілік

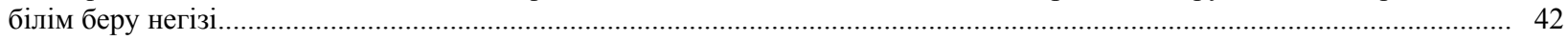

Кенжебаева Д.К., Өрмөрза Б. Ғ., Дашгин Махаммадли. Қазақстандық заманауи жастардың құндылығы............. 51

Нурманова А.Ш., Медерова Д.Е., Дюсенов Б.Д. «Бөкейхан әулетінің талдыбейіт қорымы» эпиграфикалық ескерткіштері тарихи дереккөз ретінде.

Кыдырова Ж.Ш., Онласынов Е.З., Абишова А.У., Шадиева А.А. Оңтүстік Қазақстан облысы сүт және сүт өнімдері нарығындағы жағдайды зерттеу ......

Абимова Г.У., Аманжолов Р., Мынбаева Б.Н., Ибрагимова Д.И. ЖОО-да биолог-студенттердің жобаларды

ұйымдастырылуы мен орындалуына даярлығы.......

Балтабаева А.Ю., Ризаходжаева Г. Мәдени интеграция үдерісіндегі жібек жолының феномені............................... 9

Бурганова Р.И., Абдугалина С.Е., Туякова А.Е. Студенттерге бағытталған білім беру арқылы білім сапасын

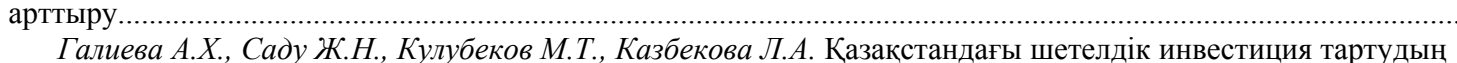

институционалдық жағдайын (талаптарын) бағалау..

Джалилов 3.Г., Батырхан Б.Ш. ХX ғ. екінші жартысындағы шетелдік исламтанушылардың ислам және саясат

туралы теориялық дискурсы.......

Джумабекова А.Т., Канатова А.Ж. Қаржылық ынтымақтастық жағдайларындағы Қазақстан республикасының

ұлттық банкінің өткізу механизмінің өзгеруі......

Дүйсен Г. М., Айтжанова Д. А. Қазақстан және Орталық Азия елдеріндегі көші-қон процесстері дамуының мәселелері мен ерекшеліктері

Есендұлова М.Н. Қазақстандағы « Қиын балаларды» оңалтудың және әлеуметтендірудің психологиялық ерекшеліктері

Жакишева К.М., Жуманова Д.Т., Мукашева Г.М. Экономиканың аграрлық секторының тұрақты дамуына арналған ауыл шаруашылық кәсіпорындарының қаржылық шарттарын мониторингінің рөлі.....

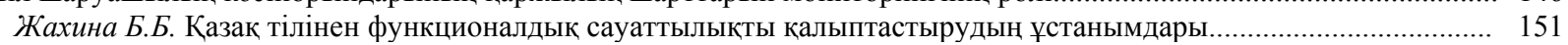

Идресова У.Х., Садуахасова 3.Ж., Муханова А.Т. Криминалистика....................................................................... 156

Савельева В. В. Қазақстандағы кредит технологиясын пайдалану және дамуының тарихи және педагогикалық базасы.

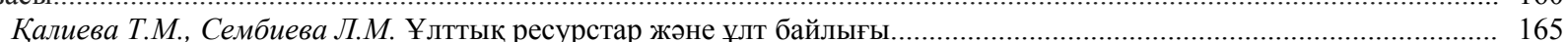

Каримова Р.У., Хаджиева Г.У. ҚХР Ұлттық саясаты контексіндегі ШҰАА-ның этносаяси және әлеуметтікэкономикалық трансформациясы мәселесі.

Керімбек Г., Молдашбаева Л., Джрауова Қ., Ажмухамедова А., Мизанова А. Қазақстан республикасының

республикалық бюджетіне түсетін салық түсімдерінің көрсеткіштерін талдау және бағалау.....

Жолдасбекова С.А., Парманкулова П.Ж., Асаналиев М.К. Мүмкіндігі шектеулі балаларды дамытудағы ұлттық ойындар

Молдакенова Е.К., Байгабулова К.К., Онаева Б.Т. БҚО-да инновациялық үрдістерді басқарудың аймақтық

аспектілігі жүйесінің дамудың жолдары.

Мұратова Г.К., Шаушенова А.Г., Жумасеитова С.Д., Онұварбаева М.Б.Білім беру үрдісінде бұлттық

технологияларын қолдану......

Несіпбеков E. Н., Аппакова Г.Н. Кәсіпорынның инвестициялық портфелін қалыптастырудың теориялық

Нургабылов М.Н., Барлыков Е.К., Егембердиева С.М. ҚР есеп өнеркәсібінің дамуының басқаруының трендсі....... 220

Нурымбетов Т.Я., Абишова А.У., Уразбаева Г.Ж., Кыдырова Ж.Ш., Байнеева П.Т., Абишо Н.У. Модернизациялық

жағдайындағы қр халқын әлеуметтік қолдауының басымдықтары.....

Рахимова С. А., Тургумбекова М. М. Қазақстан республикасындағы шағын және орта бизнестіңмемлекеттік қолдау

бағдарламалары және олардың тиімділігін жүзеге асыру шаралары.......................................................................... 233

Руденко Е.И. Орталық пен Оңтүстік Азия мемлекеттері арасындағы ұғынудың бұрмалануы - «Жұмсақ күш»

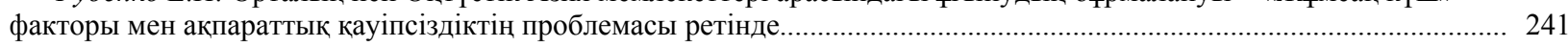

Тохтабаева Ш. Қазына-сандық.......................................................................................................... 251

Утепкалиева К.М., Сабирова Р.К., Кенбаева Г.У. Мұнай-газ секторындағы мемлекеттік-жеке серіктестікті дамыту

Мыңбаев Д. Е. Банкте басқару есебін ұйымдастыру тұжырымдамасы...

Султанова Г.С. Жаңа формацияның экономисі - бакалаврдың кәсіби құзыреттілігін қалыптастырудың

Шаяхметова А.А. Университет жағдайында инклюзивті білім беру үшін педагогтарды оқыту....... 


\section{СОДЕРЖАНИЕ}

Беспаева Р.С., Бугубаев Р.О., Мануэль Ф. Грела. Формирование комплексной стратегии развития ЩучинскоБоровской курортной зоны на основе сбалансированной системы показателей. Аюпова 3.К., Кусаинов Д.У., Уинстон Наган. Некоторые грани интеграции в совершенствовании гражданского процесса.

Кусаинова А.А., Козловски Вальдемар, Геращенко И.П. Обзор некоторых особенностей финансово-правового механизма обязательного социального страхования в республике Казахстан......

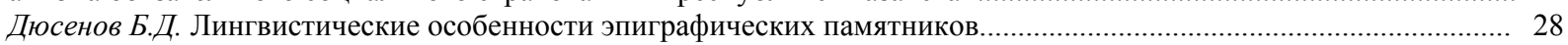

Джумадилова Ш.Г., Атабай Б.Ж.Динамика сбережений населения в Казахстане................................................... 33

Карабалина А.А., Альситова А. Б., Кереймаганбетова Ж.Н., Абишева Н. М. Ценность как базовая основа духовнонравственного образования.

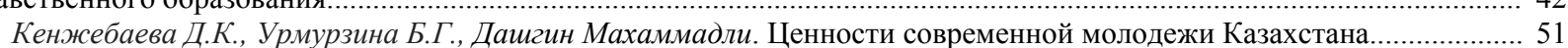

Нурманова А.Ш., Медерова Д.Е., Дюсенов Б.Д. Эпиграфические памятники «Некрополи талдыбейит династии

Бокейхановых» как исторический источник.

Кыдырова Ж.Ш., Онласынов Е.З., Абишова А.У., Шадиева А.А.Исследование ситуации на рынке молока и молочной продукции южно-казахстанской области

Абишова Г.У., Аманжолов Р., Мынбаева Б.Н., Ибрагимова Д.И. Готовность студентов-биологов к организации

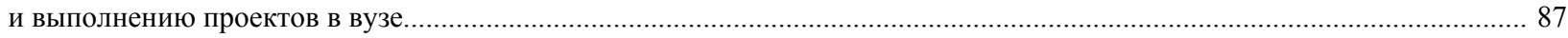

Балтабаева А.Ю., Ризаходжаева Г. Феномен великого шелкового пути в процессе культурной интеграции............... 91

Бурганова Р.И., Абдугалина С.Е., Туякова А.Е. Повышение качества образования посредством

студентоцентрированного обучения...

Галиева А.Х., Саду Ж.Н., Кулубеков М.Т., Казбекова Л.А. Оценка институциональных условий привлечения

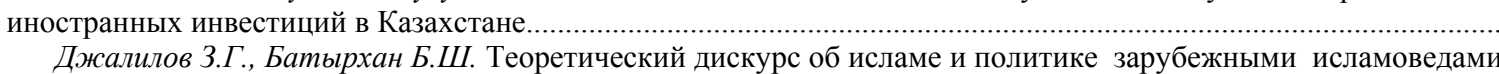
второй половины ХX в.

Джумабекова А.Т., Канатова А.Ж. Трансформация трансмиссионного механизма национального банка республики

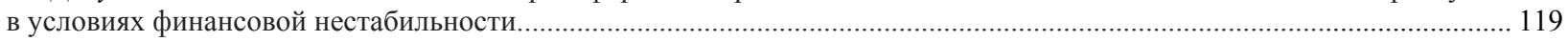

Дуйсен Г.М., Айтжанова Д.А. Проблемы и особенности развития миграционных процессов в Казахстане

и странах Центральной Азии.

Есенгулова М.Н. Психологические особенности реабилитации и социализации "Трудных подростков"

в Казахстане".

Жакишева К.М., Жуманова Д.Т., Мукашева Г.М.Роль мониторинга финансового состояния сельскохозяйственных

предприятий в обеспечении устойчивого развития аграрного сектора экономики.........................................................146

Жахина Б.Б. Принципы формирования функциональной грамотности казахского языка.......................................... 151

Идресова У.Х., Садуахасова 3.Ж., Муханова А.Т. Криминалистика......................................................................... 156

Савельева B.B. Исторические и педагогические основы формирования и разработки кредитной технологии

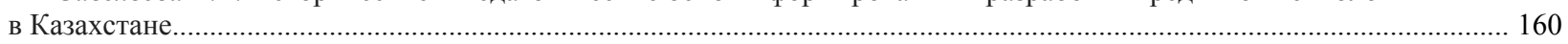

Калиева Т.М., Сембиева Л.М. Национальные ресурсы и богатство нации.................................................. 165

Каримова Р.У., Хаджиева Г.У. К вопросу об этно-политической и социально-экономической трансформации

СУАР в контексте национальной политики КНР

Керимбек Г., Молдашбаева Л., Джрауова Қ., Ажмухамедова А., Мизанова А. Анализ и оценка показателей

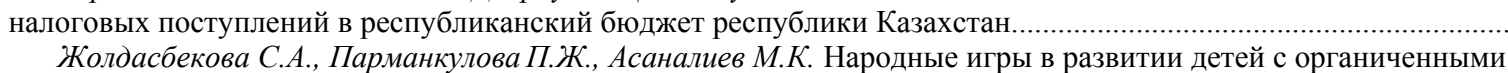

Жолдасбекова С.А., Парманкулова П.Ж., Асаналиев М.К. Народные игры в развитии детей с органиченными

Молдакенова Е.К., Байгабулова К.К., Онаева Б.Т.Пути развития системы регионального аспекта управления

инновационными процессами в АПК.

Муратова Г.К., Шаушенова А.Г., Жумасеитова С.Д., Онгарбаева М.Б. Применение облачных технологий

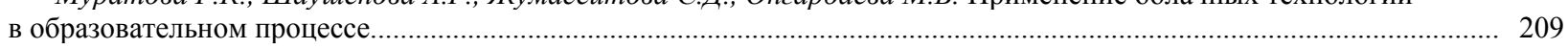

Несипбеков Е.Н., Аппакова Г.Н. Теоретические аспекты формирования инвестиционного портфеля предприятия. 214

Нургабылов М.Н., Барлыков Е.К., Егембердиева С.M. Тенденции управления развитием мясоперерабаты-

вающей отрасли в РК.

Нурымбетов Т.Я., Абишова А.У., Уразбаева Г.Ж., Кыдырова Ж.Ш., Байнеева П.Т., Абишов Н.У. Приоритеты

социальной поддержки населения РК в условиях модернизации................................................................................. 22

Рахимова С. А., Тургумбекова М. М. Программы государственной поддержки мсб в республике Казахстан и меры

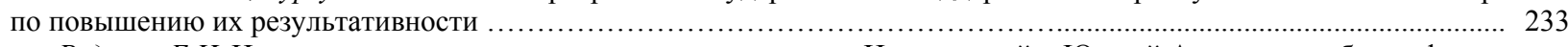

Руденко Е.И. Искаженность восприятия между государствами Центральной и Южной Азии как проблема фактора

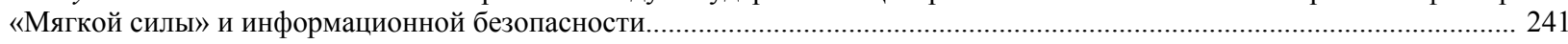

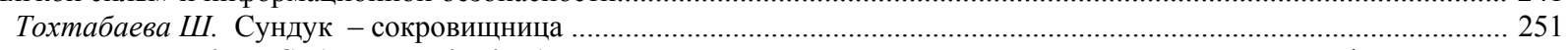

Утепкалиева К.М., Сабирова Р.К., Кенбаева Г.У.Развитие государственно-частного партнерства в нефтегазовой

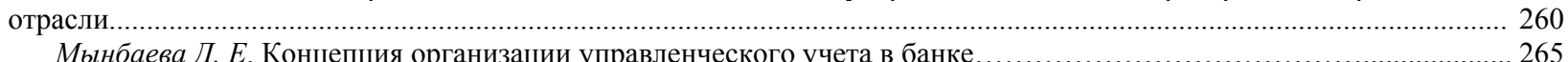

Мынбаева Д. Е. Концепция организации управленческого учета в банке...........................................2.
Султанова Г.С. Педагогические аспекты формирования профессиональных компетенций бакалавра - экономиста

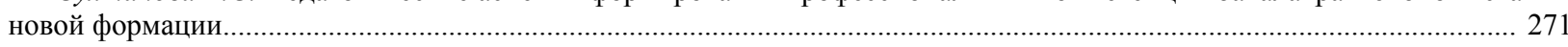

Шаяхметова А.А. О подготовке педагогических кадров к инклюзивному образованию в условиях вуза................ 277 


\section{CONTENTS}

Bespayeva R.S., Bugubayeva R.O., Manuel F. Grela. Formation of the complex strategy for development of the Schuchinsk-

Burabay resort area based on the balanced system of indicators.

Ayupova Z.K., Kussainov D.U., Winston Nagan. Some facets of integration in themodernization ofthe civil process..............13

Kussainova A.A., Kozlowski Waldemar, Gerashchenko I.P. The review of some features of the financial legal mechanism of obligatory social insurance in the republic of Kazakhstan...

Dyussenov B.D. Linguistic features of epigraphic monuments................................................................................ 28

Jumadilova Sh.G., Atabay B.Zh. Dynamics of the population savings in Kazakhstan.......................................................... 33

Karabalina A.A., Alsitova A.B., Kereimaganbetova Zh.N., Abisheva N.M. The values as critical factor of moral education... 42

Kenzhebayeva D.K., Urmurzina B.G., Dashqin Mahammadli. The modern youth values in Kazakhstan............................. 51

Nurmanova A.S., Mederova D.E., Dyussenov B.D. "Bokeykhanov dynasty taldybeyit necropolis" epigraphic monuments

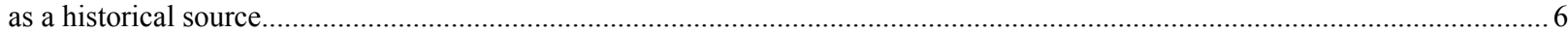

Kydyrova Zh.Sh., Onlasynov E.Z., Abishova A.U., Shadieva A.A.Research of the situation in the market of milk and dairy

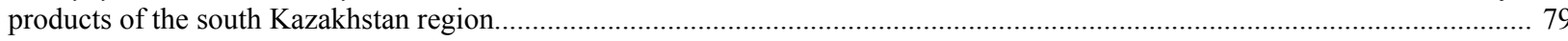

Abishova G.U., Amanzholov R.A., Mynbayeva B.N., Ibragimova D.I. Readiness of students-biologists for the organization

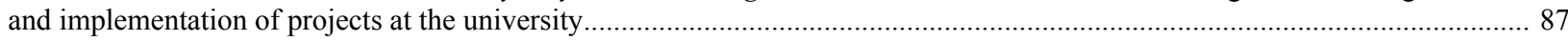

Baltabayeva A.Y., Rizakhojayeva $G$. The phenomenon of the great silk road in the cultural integration process................... 91

Burganova R.I., Abdugalina S.E., Tuyakova A.E. Improving the quality of education through student-centered education... 102

Galiyeva A.Kh., Sadu Zh.N., Kulubekov M.T., Kazbekova L.A. Assessment of the institutional terms of the foreign

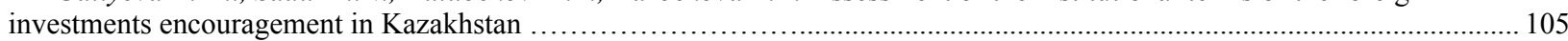

Dzhalilov Z.G. Theoretical discourse on islam and politics in foreign humanism of the second half of 20th century.......... 112

Dzhumabekova A.T., Kanatova A.ZH. Transformation of the transmission mechanism of the national bank of the republic

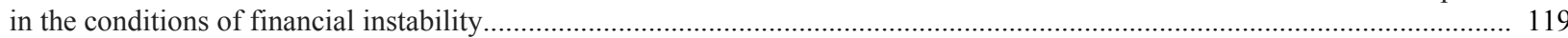

Suleimenov R.B. Problems and features of the development of migration processes in Kazakhstan and Central Asia.......... 124

Yesengulova M.N. Psychological aspects of reintegration and resocialization of "Trouble" adolescents in Kazakhstan....... 134

Zhakisheva K.M., Zhumanova D.T., Mukasheva G.M.The role of monitoring the financial condition of agricultural

enterprises in ensuring sustainable development of the agrarian sector of the economy......................................................... 146

Zhakhina B.B. Principles of functional literacy formation of the kazakh language....................................................... 151

Idresova U.Kh., Saduahasova Z.Zh., Mukhanova A.T. Criminalistics............................................................................. 156

Savelyeva $V . V$. Historicalandpedagogical bases of formation and development of credit technology in Kazakhstan........... 160

Kaliyeva T.M., Sembiyeva L.M. National Resources and national wealth.................................................................. 165

Karimova R., Hajiyeva G. Examining ethno-political and SOCIO-economic transformation of the xinjiang uyghur

autonomous region in the context of the PRC national policies........................................................................................ 176

Kerimbek G., Moldashbayeva L., Jrauova K., Azhmukhamedova A., Misanova A. Analysis and evaluation of reduction

of tax recovery of the republic of kazakhstan on the budget of the republic of Kazakhstan................................................. 185

Zholdasbekova S.A., Parmankulova P.Zh., Assanaliyev M.K. Folk games in the education of children with physical, mental and sensory disturbances..

Moldakenova E.K., Baygabulova K.K., Onaeva B.T. Ways of development of the system of the regional aspect of managing innovative processes in the APC.

Muratova G.K., Shaushenova A.G., Zhumassseitova C.D., Ongarbayeva M.B. Application of cloud technologies in the educational process......

Nurgabylov M.N., Barlikov E.K., Egemberdieva S.M. Trends of management of the development of meat processing industry in RK

Nurymbetov T.Ya., Abishova A.U., Urazbaeva G.Zh., Kydyrova Z.Sh., Baineeva P.T., Abishov N.U. Priorities of social support of the population of republic of Kazakhstan in the conditions of modernization........

Rakhimova S. A., Turgumbekova M. M. Programs of government support for sme in the republic of Kazakhstan and measures to enhance their efficiency.....

Rudenko Ye.I. Misperception between the states of Central and South Asia as a 'Soft power' and information security issue...

Tokhtabayeva Sh. Zh. Treasure-chest.

Utepkalieva K.M., Sabirova R.K., Kenbaeva G.U.Development of public private partnership approach in oil and gas

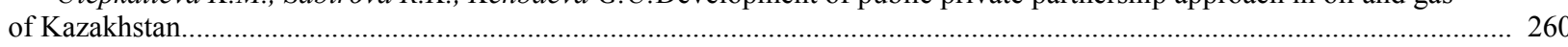

Mynbayeva D.E. Concept of organization of management accounting in bank ........................................................... 265

Sultanova G. S. Pedagogical aspects of formation of professional competence of the bachelor-economist of the new formation

Shayakhmetova A.A. On the training of teaching staff for inclusive education under the conditions of higher education institution. 


\section{PUBLICATION ETHICS AND PUBLICATION MALPRACTICE IN THE JOURNALS OF THE NATIONAL ACADEMY OF SCIENCES OF THE REPUBLIC OF KAZAKHSTAN}

For information on Ethics in publishing and Ethical guidelines for journal publication see http://www.elsevier.com/publishingethics and http://www.elsevier.com/journal-authors/ethics.

Submission of an article to the National Academy of Sciences of the Republic of Kazakhstan implies that the work described has not been published previously (except in the form of an abstract or as part of a published lecture or academic thesis or as an electronic preprint, see $\mathrm{http} / / / \mathrm{www} . e l s e v i e r . c o m / p o s t i n g p o l i c y)$, that it is not under consideration for publication elsewhere, that its publication is approved by all authors and tacitly or explicitly by the responsible authorities where the work was carried out, and that, if accepted, it will not be published elsewhere in the same form, in English or in any other language, including electronically without the written consent of the copyrightholder. In particular, translations into English of papers already published in another language are not accepted.

No other forms of scientific misconduct are allowed, such as plagiarism, falsification, fraudulent data, incorrect interpretation of other works, incorrect citations, etc. The National Academy of Sciences of the Republic of Kazakhstan follows the Code of Conduct of the Committee on Publication Ethics (COPE), and follows the COPE Flowcharts for Resolving Cases of Suspected Misconduct (http://publicationethics.org/files/u2/New_Code.pdf). To verify originality, your article may be checked by the originality detection service Cross Check http://www.elsevier.com/editors/plagdetect.

The authors are obliged to participate in peer review process and be ready to provide corrections, clarifications, retractions and apologies when needed. All authors of a paper should have significantly contributed to the research.

The reviewers should provide objective judgments and should point out relevant published works which are not yet cited. Reviewed articles should be treated confidentially. The reviewers will be chosen in such a way that there is no conflict of interests with respect to the research, the authors and/or the research funders.

The editors have complete responsibility and authority to reject or accept a paper, and they will only accept a paper when reasonably certain. They will preserve anonymity of reviewers and promote publication of corrections, clarifications, retractions and apologies when needed. The acceptance of a paper automatically implies the copyright transfer to the National Academy of sciences of the Republic of Kazakhstan.

The Editorial Board of the National Academy of sciences of the Republic of Kazakhstan will monitor and safeguard publishing ethics. 
Правила оформления статьи для публикации в журнале смотреть на сайте:

\section{www:nauka-nanrk.kz}

\section{social-human.kz}

Редакторы М.С. Ахметова, Т.А. Апендиев, Д.С. Аленов

Верстка на компьютере А.М. Кульгинбаевой

Подписано в печать 08.12.2018

Формат 60x881/8. Бумага офсетная. Печать - ризограф.

17,7 п.л. Тираж 500. Заказ 6.

Национальная академия наук $Р К$

050010, Алматы, ул. Шевченко, 28, т. 272-13-18, 272-13-19 